\title{
The importance and availability of resistant varieties in the integrated protection of oilseed rape against pathogens
}

\section{Znaczenie i dostępność odpornych odmian rzepaku w integrowanej ochronie przed organizmami chorobotwórczymi}

\author{
Ewa Jajor ${ }^{1 *}$, Marek Korbas ${ }^{1}$, Jacek Broniarz ${ }^{2}$, Joanna Horoszkiewicz-Janka ${ }^{1}$, Jan Bocianowski ${ }^{3}$
}

\begin{abstract}
Summary
The aim of the study was to define the importance of breeding cultivars resistant to pathogenic organisms and the assessment of its availability in IPM (Integrated Pest Management) of OSR (oilseed rape). The cultivation of OSR resistant or tolerant varieties in addition to agrotechnics, the use of natural elements of the ecosystem and the rational application of PPP and other agrochemicals, is one of the basic elements of the IPM. The System of Post-Registration Variety Testing (PDO) implemented in Poland allows for constant monitoring of the most important threats as well as genetic resistance of varieties under field conditions, in a diverse agro-climatic environment. The precise selection of the variety is an important element of IPM of OSR. The progress in breeding resistance to both biotic and abiotic factors is brought primarily by hybrid varieties. In recent years, this mainly applies to such economically important pathogenic organisms as: Leptosphaeria spp. (blackleg), Turnip yellow virus (TuYV) and Plasmodiophora brassicae (clubroot).
\end{abstract}

Key words: integrated plant protection, resistant varieties, breeding of rape

\section{Streszczenie}

Celem pracy było zdefiniowanie znaczenia hodowli odmian odpornych na organizmy chorobotwórcze oraz praktyczna ocena ich dostępności w integrowanej ochronie rzepaku. Uprawa odmian rzepaku odpornych lub tolerancyjnych na organizmy szkodliwe, obok agrotechniki, wykorzystania naturalnych elementów ekosystemu i racjonalnego stosowania środków ochrony roślin jest jednym z podstawowych założeń integrowanej ochrony tego gatunku. System Porejestrowego Doświadczalnictwa Odmianowego (PDO) realizowany w naszym kraju pozwala na stały monitoring zagrożeń biotycznych i ich nasilenia oraz odporności genetycznej odmian w warunkach polowych, w zróżnicowanym środowisku agroklimatycznym. Precyzyjny dobór odmiany jest ważnym elementem integrowanej uprawy i ochrony rzepaku. Postęp w hodowli odpornościowej, zarówno na czynniki biotyczne, jak i abiotyczne, wnoszą przede wszystkim odmiany mieszańcowe. W ostatnich latach dotyczy to głównie takich ważnych gospodarczo organizmów chorobotwórczych, jak: Leptosphaeria maculans (sucha zgnilizna kapustnych), Turnip yellow virus, TuYV (wirus żółtaczki rzepy) i Plasmodiophora brassicae (kiła kapusty).

Słowa kluczowe: integrowana ochrona roślin, odmiany odporne, hodowla rzepaku

\footnotetext{
${ }^{1}$ Instytut Ochrony Roślin - Państwowy Instytut Badawczy Władysława Węgorka 20, 60-318 Poznań

${ }^{2}$ Centralny Ośrodek Badania Odmian Roślin Uprawnych Słupia Wielka, 63-022 Słupia Wielka

${ }^{3}$ Uniwersytet Przyrodniczy w Poznaniu Wojska Polskiego 28, 60-637 Poznań

*corresponding author: e.jajor@iorpib.poznan.pl ORCID: 0000-0002-4412-1766
} 


\section{Wstęp / Introduction}

Od 1 stycznia 2014 roku w Polsce oraz innych krajach Unii Europejskiej stosowanie zasad integrowanej ochrony roślin stało się obowiązkiem wszystkich profesjonalnych użytkowników ochrony roślin. Integrowana ochrona polega na ochronie upraw przed organizmami szkodliwymi, z wykorzystaniem wszystkich dostępnych metod, a szczególnie metod niechemicznych, w sposób minimalizujący zagrożenie dla zdrowia ludzi, zwierząt oraz środowiska (Mrówczyński 2013).

Uprawa odmian odpornych lub tolerancyjnych na organizmy szkodliwe, obok agrotechniki, wykorzystania naturalnych elementów ekosystemu i racjonalnego stosowania środków ochrony roślin jest jednym z podstawowych założeń integrowanej ochrony rzepaku. Odporność odmian na działanie i konkurencyjną rolę czynników biotycznych (patogeny, szkodniki i chwasty) nabiera znaczenia w systemach uprawy bardziej przyjaznych naturalnemu środowisku, ponieważ można ją zaliczyć do działań proekologicznych (Mrówczyński 2013; Bartkowiak-Broda i wsp. 2017). Dąży się w nich do ograniczania chemicznej ingerencji w środowisko, w tym zwłaszcza zminimalizowania ilości stosowanych chemicznych środków ochrony roślin w polowych uprawach roślin. Problem ten ma również aspekt ekonomiczny, ponieważ każdy zabieg ochrony roślin zwiększa koszty uprawy. Oczekuje się, że hodowla odpornościowa w dużym stopniu będzie gwarantowała stabilne plonowanie odmian uprawianych w różnych siedliskach. Bezsprzecznie, stosowanie w produkcji odmian odpornych lub tolerancyjnych na różne czynniki spowoduje korzystny efekt, zarówno gospodarczy, jak i środowiskowy.

Przeciętne straty plonu nasion rzepaku wynikające z porażenia przez sprawców chorób wynoszą około 15-20\%. Jednakże niektóre patogeny mogą powodować znacznie większe straty, niekiedy dochodzące do 50-70\%, a nawet $100 \%$ potencjalnego plonowania (Jajor i wsp. 2017). Nasilenie objawów chorób zależy od wielu czynników, m.in. od struktury populacji i biologii danego patogena, uprawianych odmian, warunków klimatycznych, ale również stosowanych praktyk rolniczych, metod uprawy, ochrony roślin i interakcji między tymi czynnikami (Mrówczyński 2013). Problem ochrony rzepaku przed patogenami jest złożony i ma znacznie gospodarcze ze względu na dużą powierzchnię uprawy i duże potrzeby produkcyjne, co wiąże się z krótkim cyklem zmianowania, a to z kolei przyczynia się do namnażania czynników infekcyjnych (Bartkowiak-Broda i wsp. 2017). Rzepak może być porażany przez kilkanaście patogenów, o różnej przynależności taksonomicznej, odmiennej biologii i cyklach rozwojowych. Do najważniejszych należą Leptosphaeria maculans (Desm.) Ces. et De Not., Leptosphaeria biglobosa Shoemaker et H. Brun [Phoma lingam (Tode) Desm.] (sucha zgnilizna kapustnych), Sclerotinia sclerotiorum (Lib.) de Bary (zgnilizna twardzikowa), Alternaria brassicae (Berk.) Sacc., Alternaria brassicicola (Schw.) Wiltsh. i Alternaria alternata (Fr.) Keissl. sprawcy czerni krzyżowych, Verticillium longisporum (C. Stark) Karapapa et al., Verticillium spp. (werticilioza) oraz lokalnie coraz częściej Plasmodiophora brassicae Woronin (kiła kapusty). Pozostałe choroby mają mniejsze znaczenie i są to: zgorzel siewek (kompleks grzybów), szara pleśń [Botryotinia fuckeliana (de Bary) Whetzel, (Botrytis cinerea Pers.)], cylindrosporioza [Pyrenopeziza brassicae B. Sutton et Rawl., (Cylindrosporium concentricum Grev.)], mączniak rzekomy [Hyaloperonospora parasitica (Pers.) Fr.], mączniak prawdziwy (Erysiphe cruciferarum Opiz ex Junell), biała plamistość liści [Mycosphaerella capsellae A.J. Inman \& Sivan., (Pseudocercosporella capsellae Ellis \& Everh.] i inne (Rimmer i wsp. 2007; Jajor i wsp. 2017). Spośród wirusów występuje przede wszystkim wirus żółtaczki rzepy (Turnip yellow virus, TuYV) oraz niekiedy obserwuje się objawy infekcji wirusa mozaiki rzepaku (Turnip mosaic virus, TuMV) (Juergens i wsp. 2010).

Metoda hodowli odpornościowej polega na uzyskiwaniu przy pomocy różnych sposobów i technik hodowlanych, odmian odpornych, tolerancyjnych lub o podwyższonej odporności na porażenie przez sprawców chorób (grzyby, pierwotniaki, wirusy i inne organizmy szkodliwe). Ważna jest przy tym znajomość biologii i zdolności infekcyjnych patogena, a zwłaszcza liczby i szkodliwości występujących ras. Hodowla odpornościowa nowych odmian rzepaku ukierunkowana jest zwykle na promowanie ich tolerancji na najbardziej chorobotwórcze lub rozpowszechnione rasy określonych czynników chorobotwórczych. W trakcie prac hodowlanych, hodowcom udaje się wprowadzić do genotypów wybranych odmian geny odpowiedzialne za odporność na określonego sprawcę choroby. Należy pamiętać, że proces hodowli odmian odpornych jest procesem długotrwałym, stale monitorowanym i modyfikowanym przez wprowadzanie do odmian nowych źródeł odporności, ponieważ często dochodzi do przełamania już istniejącej odporności nabywanej przez patogeny.

Dla rozpoczęcia efektywnej hodowli odpornościowej konieczne jest przede wszystkim znalezienie i wyodrębnienie źródeł odporności, wyznaczenie wzorców podatności i odporności na dany patogen oraz poznanie genomu sprawcy choroby, jak i genomu gospodarza. Korzystne jest posiadanie wielu źródeł odporności, które zastosowane w hodowli odmian pozwolą na wykorzystanie ich w walce z poszczególnymi rasami. Ciągła praca hodowlana w kierunku zwiększenia odporności odmian rzepaku, w wyniku kumulacji odporności poligenicznej oraz rasowo-specyficznej, umożliwić może kontrolę nasilenia objawów chorób poprzez wprowadzenie do uprawy odmian odpornych lub tolerancyjnych (Bartkowiak-Broda i wsp. 2017).

$\mathrm{W}$ procesie badań rejestracyjnych nowych odmian rzepaku, w doświadczeniach polowych, oprócz ilości i jakości 
plonu, oceniana jest odporność na patogeny oraz inne czynniki, m.in. zimotrwałość, wyleganie, czy osypywanie nasion. Niestety, odporność odmian na poszczególnych sprawców chorób nie jest całkowita i nabyta trwale. Przeważnie odmiany są odporne tylko na jednego patogena, rzadziej na dwa lub więcej. W przypadku skutecznych infekcji roślin o wysokiej tolerancji na wybrany czynnik chorobotwórczy, przebieg choroby jest łagodny. Obecnie w Krajowym Rejestrze wpisanych jest ponad 150 odmian rzepaku ozimego, z czego trzy czwarte stanowią odmiany mieszańcowe. Odsetek odmian populacyjnych w ostatnich latach stopniowo maleje. W przypadku rzepaku jarego, w Krajowym Rejestrze znajduje się blisko 30 odmian, a niemal połowa z nich to odmiany mieszańcowe (Broniarz 2017).

Porejestrowe Doświadczalnictwo Odmianowe (PDO) umożliwia natomiast stały, tj. coroczny monitoring najistotniejszych zagrożeń, w tym występowania chorób i ich nasilenia oraz odporności odmian rzepaku wpisanych do Krajowego Rejestru, badanych w warunkach polowych, w zróżnicowanych pod względem agroklimatycznym środowiskach. Obserwacje te są istotnym źródłem aktualnej wiedzy nie tylko dla praktyki rolniczej, ale także dla hodowców i wyznaczają kierunek dalszych badań.

Odmiany mieszańcowe rzepaku cechują się ogólnie większym potencjałem plonowania niż odmiany populacyjne. Hybrydy reagują mniejszą redukcją plonu na niesprzyjające czynniki np. niekorzystne zjawiska atmosferyczne, czy opóźnione siewy. Jest to możliwe ze względu na ich szybki rozwój początkowy i wydajny system korzeniowy, co pozwala na efektywne pobieranie wody i składników pokarmowych. Odmiany mieszańcowe wnoszą także postęp w hodowli odpornościowej, w której tworzy się linie syntetyczne dla wprowadzania genów determinujących odporność. W ostatnich latach dotyczy to głównie takich ważnych gospodarczo chorób, jak sucha zgnilizna kapustnych, kiła kapusty i wirus żółtaczki rzepy.

Priorytetem w hodowli rzepaku powinno być łączenie w tworzonych odmianach różnych korzystnych właściwości. Najlepiej jest, gdy w pracach hodowlanych, oprócz plonowania na wysokim poziomie, uwzględni się zarówno cechy odpornościowe, jak i pożądane cechy użytkowe, między innymi dobrą zimotrwałość, zwiększoną odporność na pękanie łuszczyn oraz osypywanie nasion. Pozwala to uzyskać w uprawie polowej istotne korzyści, dotyczące zarówno ilości, jak i jakości plonu nasion (Broniarz 2017).

Precyzyjnie dobrane odmiany są ważnym elementem integrowanej uprawy i ochrony rzepaku. Dla upowszechnienia integrowanej ochrony niezbędne jest prowadzenie doświadczeń, które pozwolą dokładnie ocenić odporność odmian na najważniejsze patogeny i inne czynniki, a także określić ich wymagania agrotechniczne.

Podstawowym celem pracy było zdefiniowanie znaczenia hodowli odmian odpornych na organizmy chorobotwórcze oraz praktyczna ocena ich dostępności w integrowanej ochronie rzepaku.

\section{Materiały i metody / Materials and methods}

Doświadczenia porejestrowe (PDO) z odmianami rzepaku prowadzono według metodyki stosowanej w badaniach Centralnego Ośrodka Badania Odmian Roślin Uprawnych (COBORU) (Rzepak. Metodyka badania wartości gospodarczej odmian (WGO). COBORU, Słupia Wielka 2008). Były to doświadczenia polowe, realizowane w blisko 30 miejscowościach (Stacjach i Zakładach Doświadczalnych Oceny Odmian) rozmieszczonych na terenie prawie całego kraju w różnych warunkach siedliskowych. Doświadczenia założono w układzie 1-rozkładalnych bloków niekompletnych, w trzech powtórzeniach. Powierzchnia poletka doświadczalnego wynosiła $15 \mathrm{~m}^{2}$. W poszczególnych sezonach wegetacyjnych (2015-2019) badano od 65 do 76 odmian rzepaku ozimego i od 15 do 19 odmian rzepaku jarego. Doświadczenia realizowano jako jednoczynnikowe, tj. odmianowe, przy średnio intensywnym poziomie agrotechniki, który obejmował podstawowe zabiegi agrotechniczne, w tym nawożenie NPK $+\mathrm{S}+$ mikroelementy, zwalczanie chwastów i ochronę przed szkodnikami. W niektórych doświadczeniach, w zależności od potrzeb, zastosowano również standardową ochronę przy użyciu fungicydów. W doświadczeniach wykonywano obserwacje porażenia roślin badanych odmian przez organizmy chorobotwórcze. Obserwacje wykonywano w kilku losowo wytypowanych miejscach na poletku lub na wybranych rzędach. Przed przystąpieniem do oceny nasilenia występowania choroby, dokonywano obserwacji symptomów i mikroskopowej identyfikacji patogena. Nasilenie występowania objawów porażenia oceniano szacunkowo na różnych częściach rośliny (szyjka korzeniowa, łodyga, liść, łuszczyna), przyjmując zasadę obserwacji w terminie największego zróżnicowania badanych odmian. Ocenę porażenia roślin przez sprawców szarej pleśni, mączniaka prawdziwego i rzekomego oraz suchej zgnilizny kapustnych wykonywano najczęściej w fazie od wzrostu pędu głównego do wykształcenia pierwszych łuszczyn (BBCH 50-72), a ocenę występowania objawów chorób podstawy łodygi, zgnilizny twardzikowej i czerni krzyżowych przeprowadzano w fazie dojrzewania (BBCH 80-82). Objawy występujące na wszystkich roślinach (mączniak prawdziwy, mączniak rzekomy, czerń krzyżowych), w różnym nasileniu na poszczególnych organach oceniano w skali $9^{\circ}$ (9 - oznacza brak objawów porażenia, 5 - porażenie średnie, 1 - porażenie bardzo duże). Natomiast objawy występujące na niektórych roślinach oceniano szacując udział porażonych roślin na poletku $\mathrm{w}$ procentach (choroby podstawy łodygi, sucha zgnilizna kapustnych, zgnilizna twardzikowa). Częstość występowania chorób w rzepaku ozimym i rzepaku jarym, określoną jako procent doświadczeń, w których wystąpiło porażenie roślin przez patogena, w stosunku do doświadczeń zebranych $\mathrm{w}$ danym roku, przedstawiono na wykresach zmiennych równoległych (wykresy typu „,sieć rybacka”) (rys. 1,2). 


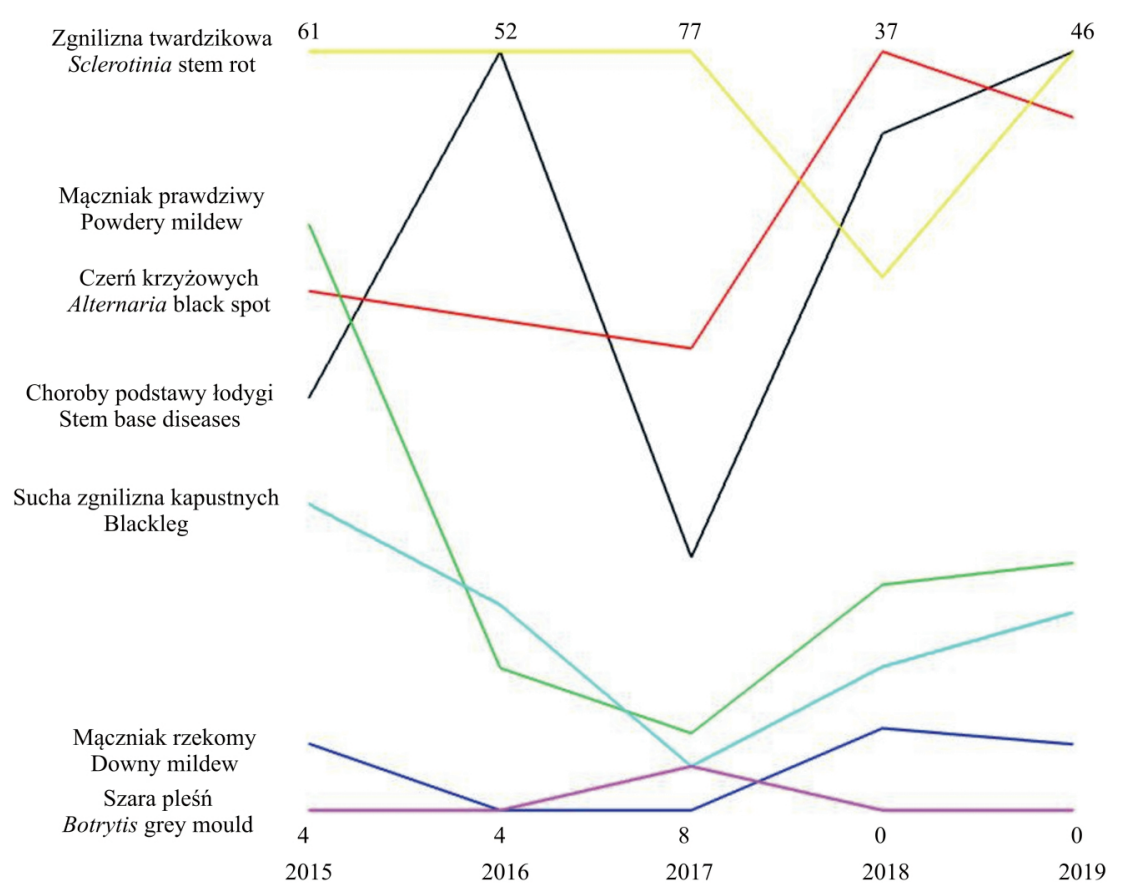

Rys. 1. Sieć rybacka dla siedmiu chorób rzepaku ozimego obserwowanych w doświadczeniach PDO (2015-2019)

Fig. 1. Parallel coordinate plot for seven winter rape diseases observed in PDO experiments (2015-2019)

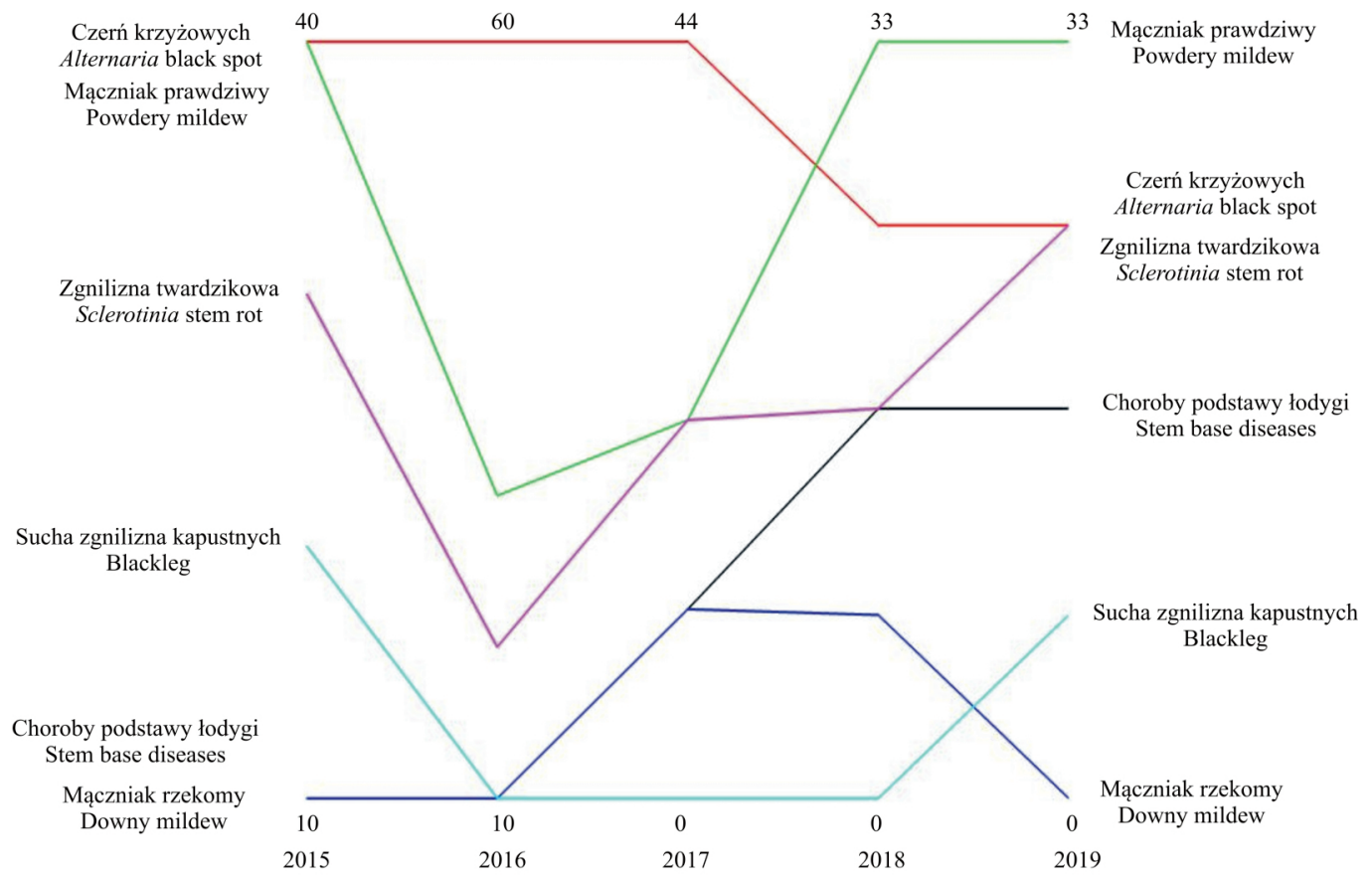

Rys. 2. Sieć rybacka dla sześciu chorób w rzepaku jarym obserwowanych w doświadczeniach PDO (2015-2019)

Fig. 2. Parallel coordinate plot for six spring rape diseases observed in PDO experiments (2015-2019)

W związku z wystąpieniem na roślinach w jednej z lokalizacji w sezonie 2018/2019, w ramach doświadczeń PDO, objawów porażenia przez P. brassicae (kiła kapusty) porównano plon wybranych odmian. Po zbiorze analizowano plon nasion 4 odmian rzepaku nieodpornych na porażenie (Architect, DK Expiro, ES Valegro, SY Ilona) oraz 4 od- mian o podwyższonej odporności na infekcję przez sprawcę kiły kapusty (Alasco, Augusta, DK Palinum, SY Alibaba). Plon nasion określano przy wilgotności nasion na poziomie 9\%. Zgodność rozkładu empirycznego plonu rzepaku $\mathrm{z}$ rozkładem normalnym sprawdzono $\mathrm{z}$ wykorzystaniem testu Shapiro-Wilka. Jednoczynnikowa analiza wariancji 
(ANOVA) została przeprowadzona w celu określenia efektu odmiany na zmienność obserwowanego plonu rzepaku. Obliczono charakterystyki pozycyjne (wartości: minimalną, średnią, maksymalną i medianę) oraz odchylenie standardowe obserwowanej cechy dla każdej z badanych odmian. Obliczono najmniejszą istotną różnicę (NIR 0,05) i na jej podstawie wyznaczono grupy jednorodne. Wszystkie obliczenia w zakresie analizy statystycznej przeprowadzono z wykorzystaniem programu GenStat v. 18 .

\section{Wyniki i dyskusja / Results and discussion}

Obserwacje porażenia odmian w doświadczeniach porejestrowych (PDO) wskazują, że w naszym kraju rośliny rzepaku ozimego najczęściej atakowane są przez patogeny powodujące zgniliznę twardzikową, czerń krzyżowych i choroby podstawy łodygi (tab. 1). Do kompleksu mikroorganizmów powodujących choroby podstawy łodygi zalicza się przede wszystkim Fusarium spp., Rhizoctonia spp., Phoma lingam, B. cinerea, Olpidium brassicae i inne. Obserwowane są one w dolnej części łodygi z reguły w okresie dojrzewania roślin. Coraz częściej zauważalne jest także porażenie roślin przez Verticillium spp. W małej liczbie doświadczeń obserwowano porażenie roślin przez sprawców mączniaka prawdziwego, mączniaka rzekomego i szarej pleśni. Potwierdza to rezultaty wcześniejszych opracowań, gdzie pod względem szkodliwości w rzepaku ozimym, najczęściej wymienia się zgniliznę twardzikową, suchą zgniliznę kapustnych oraz czerń krzyżowych (Jędryczka 2006; Jajor i wsp. 2008, 2010; Broniarz 2017). Częstotliwość występowania ww. chorób w dużym stopniu uzależniona jest od udziału uprawy rzepaku w rejonie i możliwości kumulowania form przetrwalnikowych grzybów w agrocenozach (Korbas i wsp. 2008). Wiele patogenów rozwija się intensywniej w wybranych sezonach i rejonach kraju w panujących wówczas optymalnych zakresach tolerancji ekologicznej względem warunków termiczno-wilgotnościowych grzybów.
Poszczególne lata prowadzenia obserwacji były bardzo zróżnicowane pod względem częstości występowania ważnych gospodarczo chorób w rzepaku ozimym. Zgnilizna twardzikowa częściej występowała w 2015, 2016, 2017 i 2019 roku, natomiast czerń krzyżowych w 2018, przy czym w 2017 roku czerń krzyżowych wystąpiła aż w 50\% doświadczeń. W stosunkowo wilgotnym 2017 roku porażenie przez S. sclerotiorum wystąpiło powszechnie, bo aż w blisko 80 procentach doświadczeń, odmiennie, w suchym 2018 roku zgniliznę twardzikową obserwowano na roślinach rzepaku ozimego jedynie w kilku doświadczeniach. W przypadku chorób podstawy łodygi, infekcja była odnotowana częściej w 2016 i 2019 roku. Stosunkowo rzadko obserwowano objawy porażenia roślin przez patogeny powodujące mączniaka prawdziwego i rzekomego oraz szarą pleśń. Szara pleśń nie występowała w 2018 i 2019 roku. Na rysunku 1. przedstawiono częstość występowania podstawowych chorób w rzepaku ozimym obserwowanych w pięciu latach badań i zilustrowanych na wykresie typu ,sieć rybacka”.

Wyniki ocen średniego porażenia roślin dla wszystkich badanych odmian oraz dodatkowo odmian populacyjnych i mieszańcowych z lat 2015-2019 przedstawiono w tabeli 2. Porażenie odmian badanych w doświadczeniach PDO wynosiło średnio 14\% przez sprawców chorób podstawy łodygi, 8\% suchej zgnilizny kapustnych, 13\% zgnilizny twardzikowej i 7,3 stopnia (w skali $9^{\circ}$ ) w przypadku czerni krzyżowych. Przeciętnie, odmiany populacyjne i mieszańcowe były w równym stopniu porażane przez występujących sprawców chorób. Różnica w nasileniu porażenia odmian przez mikroorganizmy powodujące choroby podstawy łodygi wyniosła 10-11\% w obu grupach odmian. Porażenie odmian przez Leptosphaeria spp. było bardziej zróżnicowane w odmianach mieszańcowych i wynosiło skrajnie $10 \%$, natomiast $\mathrm{w}$ odmianach populacyjnych jedynie $6 \%$. W przypadku porażenia odmian przez S. sclerotiorum skrajnie różnica porażenia wśród odmian populacyjnych wyniosła 11\%, a wśród odmian mieszańcowych 13\%. Przeciętnie $\mathrm{w}$ równym stopniu były porażane odmiany populacyjne i mieszańcowe przez Alternaria spp.

Tabela 1. Częstość występowania podstawowych chorób w rzepaku ozimym (liczba doświadczeń, w których wystąpiły poszczególne choroby/liczba doświadczeń zebranych) [COBORU, doświadczenia PDO 2015-2019]

Table 1. The frequency of basic diseases in winter oilseed rape (number of experiences with particular diseases/number of collected experiences) [COBORU, PDO experiments 2015-2019]

\begin{tabular}{l|c|c|c|c|c|c}
\hline \multicolumn{1}{c|}{ Choroby - Diseases } & $\begin{array}{c}\text { Średnia } \\
\text { Average }\end{array}$ & 2019 & 2018 & 2017 & 2016 & 2015 \\
\hline Choroby podstawy łodygi - Stem base diseases [\%] & $50 / 128$ & $12 / 26$ & $9 / 27$ & $8 / 26$ & $12 / 23$ & $9 / 26$ \\
\hline Czerń krzyżowych - Alternaria black spot [skala 9 $\left.{ }^{\circ}\right]$ & $53 / 128$ & $11 / 26$ & $10 / 27$ & $13 / 26$ & $8 / 23$ & $11 / 26$ \\
\hline Mączniak prawdziwy - Powdery mildew [skala 9 $\left.{ }^{\circ}\right]$ & $26 / 128$ & $4 / 26$ & $3 / 27$ & $4 / 26$ & $3 / 23$ & $12 / 26$ \\
\hline Mączniak rzekomy - Downy mildew [skala 9] & $7 / 128$ & $1 / 26$ & $1 / 27$ & $2 / 26$ & $1 / 23$ & $2 / 26$ \\
\hline Sucha zgnilizna kapustnych - Blackleg [\%] & $19 / 128$ & $3 / 26$ & $2 / 27$ & $3 / 26$ & $4 / 23$ & $7 / 26$ \\
\hline Szara pleśń - Botrytis grey mould [skala 9 $\left.{ }^{\circ}\right]$ & $5 / 128$ & $0 / 26$ & $0 / 27$ & $3 / 26$ & $1 / 23$ & $1 / 26$ \\
\hline Zgnilizna twardzikowa - Sclerotinia stem rot [\%] & $67 / 128$ & $12 / 26$ & $7 / 27$ & $20 / 26$ & $12 / 23$ & $16 / 26$ \\
\hline
\end{tabular}


Spośród zarejestrowanych odmian rzepaku ozimego można wyodrębnić takie, które w mniejszym stopniu są porażane przez patogeny powodujące suchą zgniliznę kapustnych, zgniliznę twardzikową, choroby podstawy łodygi i czerń krzyżowych. Wśród wpisanych do Krajowego Rejestru odmian, większość stanowią odmiany wykazujące średnią odporność na porażenie przez najczęściej występujące organizmy chorobotwórcze. Wyniki odporności dla tych odmian są na bieżąco aktualizowane i podawane w publikacjach dostępnych dla praktyki rolniczej np. w „Liście opisowej odmian” czy Zaleceniach IOR - PIB. Nowe odmiany przeważnie mają dobrą ogólną zdrowotność i najczęściej przejawiają podwyższoną odporność, na co najmniej jednego sprawcę choroby. Cechy te nie są trwałe i mogą ulec przełamaniu w wyniku np. silnej presji patogena (Broniarz 2017). Większa odporność odmian ma szczególne znaczenie w latach o dużym nasileniu występowania sprawców chorób. $Z$ reguły odmiany takie porażane są w mniejszym stopniu i tym samym reagują mniejszą obniżką plonowania.

W tabeli 3. przedstawiono liczbę doświadczeń w rzepaku jarym, w których obserwowano występowanie poszczególnych chorób w okresie pięciu lat i średnią z lat badań.
W przypadku formy jarej rzepaku, w doświadczeniach PDO dość powszechnie obserwowano porażenie roślin przez sprawców czerni krzyżowych i mączniaka prawdziwego oraz zgnilizny twardzikowej, rzadziej przez patogeny powodujące choroby podstawy łodygi i mączniaka rzekomego. Na rzepaku jarym czerń krzyżowych uważana jest za najgroźniejszą chorobę, a w następnej kolejności wskazuje się dla tej formy mączniaka prawdziwego, mączniaka rzekomego oraz zgniliznę twardzikową (Majchrzak i wsp. 2002; Kurowski i Budzyński 2003).

Częstość występowania chorób w rzepaku jarym obserwowanych w pięciu latach badań (2015-2019) przedstawiono na rysunku 2. Czerń krzyżowych najczęściej występowała w 2015, 2016 i 2017 roku. Natomiast mączniak prawdziwy w 2015, 2018 i 2019 roku. We wszystkich latach badań obserwowano objawy zgnilizny twardzikowej. Natomiast sucha zgnilizna kapustnych nie występowała w 2017 i 2018 roku, a mączniak rzekomy w 2019 roku.

Średnie porażenie przez patogeny odmian populacyjnych i mieszańcowych rzepaku jarego badanych w doświadczeniach PDO w pięcioleciu (2015-2019) wyniosło $12 \% \mathrm{w}$ przypadku chorób podstawy łodygi, $7 \%$ przez sprawcę zgnilizny twardzikowej oraz 7,4 stopnia w skali $9^{\circ}$

Tabela 2. Nasilenie występowania chorób na odmianach rzepaku ozimego (średnia z lat 2015-2019) [COBORU, doświadczenia PDO] Table 2. Severity of the occurrence of diseases in winter oilseed rape cultivars (2015-2019 average) [COBORU, PDO experiments]

\begin{tabular}{|c|c|c|c|c|}
\hline \multirow[t]{2}{*}{ Wyszczególnienie - Specification } & $\begin{array}{c}\text { Choroby podstawy } \\
\text { łodygi } \\
\text { Stem base diseases }\end{array}$ & $\begin{array}{c}\text { Sucha zgnilizna } \\
\text { kapustnych } \\
\text { Blackleg }\end{array}$ & $\begin{array}{c}\text { Zgnilizna } \\
\text { twardzikowa } \\
\text { Sclerotinia stem rot }\end{array}$ & \multirow{2}{*}{$\begin{array}{l}\text { Czerń krzyżowych } \\
\text { Alternaria black spot } \\
\text { porażenie w skali } 9^{\circ} \\
\text { infection in scale } 9^{\circ}\end{array}$} \\
\hline & \multicolumn{3}{|c|}{$\%$ roślin porażonych $-\%$ infected } & \\
\hline Średnia - Average & 14 & 8 & 13 & 7,3 \\
\hline Odmiany populacyjne - Population varieties: & 14 & 7 & 13 & 7,2 \\
\hline - zakres - scope & $10-20$ & $4-10$ & $8-19$ & $6,9-7,6$ \\
\hline - różnica - difference & 10 & 6 & 11 & 0,7 \\
\hline Odmiany mieszańcowe - Hybrid varieties: & 14 & 8 & 13 & 7,3 \\
\hline - zakres - scope & $10-21$ & $4-14$ & $7-20$ & $6,9-7,7$ \\
\hline - różnica - difference & 11 & 10 & 13 & 0,8 \\
\hline
\end{tabular}

Tabela 3. Częstość występowania podstawowych chorób w rzepaku jarym (liczba doświadczeń, w których wystąpiły poszczególne choroby/liczba doświadczeń zebranych) [COBORU, doświadczenia PDO 2015-2019]

Table 3. Incidence of the main diseases in spring rape (number of trials with particular diseases/number of experiences collected) [COBORU, PDO trials 2015-2019]

\begin{tabular}{l|c|c|c|c|c|c}
\hline \multicolumn{1}{c|}{ Choroby - Diseases } & $\begin{array}{c}\text { Średnia } \\
\text { Average }\end{array}$ & 2019 & 2018 & 2017 & 2016 & 2015 \\
\hline Choroby podstawy łodygi - Stem base diseases [\%] & $7 / 53$ & $2 / 12$ & $2 / 12$ & $1 / 9$ & $1 / 10$ & $1 / 10$ \\
\hline Czerń krzyżowych - Alternaria black spot [skala 9] & $20 / 53$ & $3 / 12$ & $3 / 12$ & $4 / 9$ & $6 / 10$ & $4 / 10$ \\
\hline Mączniak prawdziwy - Powdery mildew [skala 9] & $17 / 53$ & $4 / 12$ & $4 / 12$ & $2 / 9$ & $3 / 10$ & $4 / 10$ \\
\hline Mączniak rzekomy - Downy mildew [skala 9] & $4 / 53$ & $0 / 12$ & $1 / 12$ & $1 / 9$ & $1 / 10$ & $1 / 10$ \\
\hline Sucha zgnilizna kapustnych - Blackleg [\%] & $4 / 53$ & $1 / 12$ & $0 / 12$ & $0 / 9$ & $1 / 10$ & $2 / 10$ \\
\hline Zgnilizna twardzikowa - Sclerotinia stem rot [\%] & $12 / 53$ & $3 / 12$ & $2 / 12$ & $2 / 9$ & $2 / 10$ & $3 / 10$ \\
\hline
\end{tabular}


przez grzyby powodujące czerń krzyżowych i 6,7 stopnia w przypadku mączniaka prawdziwego (tab. 4). Odmiany populacyjne były średnio $w$ nieco większym stopniu porażane przez najczęściej występujące patogeny niż odmiany mieszańcowe. Występowanie chorób podstawy łodygi było bardziej zróżnicowane na odmianach populacyjnych i wynosiło skrajnie $9 \%$, natomiast na odmianach mieszańcowych $7 \%$. Nasilenie porażenia odmian przez S. sclerotiorum było takie samo w obu grupach odmian i wyniosło 5\%. Skrajnie, różnica porażenia przez sprawców czerni krzyżowych i mączniaka prawdziwego wśród odmian populacyjnych była większa i wyniosła odpowiednio 0,7 i 0,6 stopnia w skali $9^{\circ}$, natomiast w odmianach mieszańcowych ta różnica maksymalnie wyniosła 0,5 stopnia, zarówno w odniesieniu do czerni krzyżowych, jak i mączniaka prawdziwego.

Podkreślenia wymaga to, że z kilkoma ważnymi patogenami rzepaku ozimego możemy już skutecznie walczyć, używając do siewu odmiany z genami odporności. Na przestrzeni ostatnich lat widać wyraźny postęp w dostępności takich odmian. Począwszy od 2014 roku, gdy zaczęły obowiązywać zasady integrowanej ochrony roślin, stopniowo przybywa odmian o deklarowanej przez zgłaszających odporności na określonego patogena (tab. 5).
Wykorzystywana obecnie w praktyce rolniczej odporność genetyczna obejmuje takie patogeny, jak: P. brassicae, L. maculans, TuYV - Turnip yellows virus.

$\mathrm{W}$ wielu rejonach uprawy rzepaku obserwuje się wzrost znaczenia pierwotniaka $P$. brassicae sprawcy kily kapusty (Korbas i wsp. 2009; Rolfe i wsp. 2016). Jego stopień przeżywalności zależy od właściwości fizycznych, chemicznych i biologicznych gleby. W Europie izolaty P. brassicae pobrane z pola wykazują dużą zmienność, a także charakteryzują się tendencją do przełamywania odporności pochodzącej zarówno z Brassica rapa, jak i Brassica oleracea, stąd duża liczba patotypów (Hirani i Genyi 2015; Ricarova i wsp. 2016). W przypadku tej choroby nie ma praktycznej możliwości chemicznego zwalczania jej sprawcy. Głównym sposobem ograniczenia skutków wystąpienia kiły kapusty jest uprawa odmian o większej odporności na porażenie oraz szereg zabiegów agrotechnicznych, w tym przede wszystkim odpowiednio długi okres przerwy w uprawie rzepaku (Korbas i wsp. 2009).

Pierwszą zarejestrowaną w Niemczech, w 2001 roku, odmianą o wysokiej odporności na porażenie przez $P$. brassicae była odmiana Mendel (NPZ - HG. Lembke). Odmiana jest mieszańcem zrestorowanym, charakteryzującym się od-

Tabela 4. Nasilenie występowania chorób na odmianach rzepaku jarego (średnia z lat 2015-2019) [COBORU, doświadczenia PDO] Table 4. Severity of the occurrence of diseases in spring oilseed rape cultivars (2015-2019 average) [COBORU, PDO experiments]

\begin{tabular}{|c|c|c|c|c|}
\hline \multirow{2}{*}{ Wyszczególnienie - Specification } & $\begin{array}{c}\text { Choroby podstawy } \\
\text { łodygi } \\
\text { Stem base diseases }\end{array}$ & $\begin{array}{c}\text { Zgnilizna } \\
\text { twardzikowa } \\
\text { Sclerotinia } \text { stem rot }\end{array}$ & $\begin{array}{l}\text { Czerń krzyżowych } \\
\text { Alternaria black spot }\end{array}$ & $\begin{array}{l}\text { Mączniak prawdziwy } \\
\text { Powdery mildew }\end{array}$ \\
\hline & \multicolumn{2}{|c|}{$\begin{array}{l}\% \text { roślin porażonych } \\
\% \text { infected }\end{array}$} & \multicolumn{2}{|c|}{$\begin{array}{l}\text { porażenie w skali } 9^{\circ} \\
\text { infection in scale } 9^{\circ}\end{array}$} \\
\hline Średnia-Average & 12 & 7 & 7,4 & 6,7 \\
\hline Odmiany populacyjne - Population varieties: & 14 & 7 & 7,3 & 6,6 \\
\hline - zakres - scope & $9-18$ & $5-10$ & $7,1-7,8$ & $6,2-6,8$ \\
\hline - różnica - difference & 9 & 5 & 0,7 & 0,6 \\
\hline Odmiany mieszańcowe - Hybrid varieties: & 11 & 6 & 7,4 & 6,7 \\
\hline - zakres - scope & $9-16$ & $4-9$ & $7,2-7,7$ & $6,4-6,9$ \\
\hline - różnica - difference & 7 & 5 & 0,5 & 0,5 \\
\hline
\end{tabular}

Tabela 5. Odmiany rzepaku ozimego o deklarowanej przez zgłaszających odporności na patogeny w latach 2014-2019

Table 5. Varieties of winter oilseed rape with resistance to pathogens declared by the reporting persons in 2014-2019

\begin{tabular}{|c|c|c|c|c|c|c|}
\hline Wyszczególnienie - Specification & 2019 & 2018 & 2017 & 2016 & 2015 & 2014 \\
\hline $\begin{array}{l}\text { Liczba odmian zgłoszonych do Krajowego } \\
\text { Rejestru - Number of varieties reported } \\
\text { to the National List of Varieties (NLI) }\end{array}$ & 96 & 93 & 100 & 89 & 104 & 98 \\
\hline $\begin{array}{l}\text { Liczba odmian o deklarowanej odporności na } \\
\text { patogeny - Number of varieties with declared } \\
\text { resistance to pathogens }\end{array}$ & 59 & 48 & 45 & 39 & 30 & 24 \\
\hline $\begin{array}{l}\text { Procent odmian o deklarowanej odporności na } \\
\text { patogeny - Percentage of varieties } \\
\text { with declared resistance to pathogens }\end{array}$ & 61 & 52 & 45 & 44 & 29 & 25 \\
\hline
\end{tabular}


pornością rasowo-specyficzną na $P$. brassicae. Odporność tej odmiany wywodzi się z resyntetyzowanej linii Brassica napus: B. rapa ECD-04 × B. oleracea ECD-15 (Diderichsen i Sacristan 1996). Posiada ona przynajmniej 1 dominujący gen odporności A z B. rapa i 2 recesywne z $B$. oleracea (Diderichsen i wsp. 2006). W Polsce odmianę o wysokiej odporności po raz pierwszy zarejestrowano w 2014 roku i była to odmiana SY Alister (Syngenta). Obecnie w Krajowym Rejestrze w Polsce wpisanych jest 9 odmian pochodzących z czterech firm hodowlanych (Limagrain, Rapool, Monsanto/Bayer, Syngenta). Liczba wpisanych odmian do Krajowego Rejestru jest podobna, jak w innych krajach Unii Europejskiej. W sezonie wegetacyjnym 2019/2020 w badaniach urzędowych COBORU znajduje się kolejnych 18 nowych odmian o deklarowanej przez hodowców odporności na $P$. brassicae.

W pracy porównano plonowanie wybranych odmian rzepaku ozimego w doświadczeniu polowym, w warunkach silnej infekcji przez sprawcę kiły kapusty. Odmiany o potwierdzonej odporności na $P$. brassicae, które były badane w tym doświadczeniu zdecydowanie lepiej plonowały niż odmiany nieodporne. Średni plon nasion odmian nieodpornych wyniósł $0,94 \mathrm{t} \mathrm{z} \mathrm{ha,} \mathrm{podczas} \mathrm{gdy} \mathrm{średni} \mathrm{plon} \mathrm{od-}$ mian odpornych $-3,81 \mathrm{t} z$ ha. Rozkład obserwowany plonu rzepaku był zgodny z rozkładem normalnym. Wyniki analizy wariancji wskazują na istotne zróżnicowanie w wartościach plonu pomiędzy badanymi odmianami rzepaku (tab. 6). Średnio istotnie większy plon rzepaku zaobserwowano u odmian o dużej odporności na P. brassicae: Augusta, SY Alibaba, Alasco i DK Platinium. Drugą grupę jednorodną stanowią odmiany: Architect, DK Expiro, ES Valegro i SY Ilona, będące nieodpornymi na porażenie przez sprawcę kiły kapusty odmianami wzorcowymi w badaniach podstawowych COBORU. Odmiany te uzyskały średnio istotnie niższe plony. W przypadku niektórych powtórzeń, dla odmian nieodpornych, praktycznie nie uzyskano plonu. $\mathrm{Z}$ powyższych danych wynika, jak duże straty plonu nasion rzepaku ozimego może powodować kiła kapusty i jak istotne znaczenie gospodarcze ma w warunkach zagrożenia przez P. brassicae, uprawa odmian o podwyższonej odporności (fot. 1). Znajduje to potwierdzenie w wielu innych pracach badawczych oraz w praktyce rolniczej (Strelkov i wsp. 2006; Korbas i wsp. 2009; Ricarova i wsp. 2016).

W ostatnich latach, w wielu ośrodkach hodowlanych, trwają intensywne poszukiwania ,źródeł odporności” również na innych sprawców chorób rzepaku. Z powodzeniem wprowadzane są m.in. do nowych odmian geny $R \operatorname{lm} 9, \operatorname{Rlm} 7$, Rlm3 oraz Apr37, determinujące zwiększoną odporność na określone patotypy sprawców suchej zgnilizny kapustnych. Wyodrębniono dwa typy odporności na chorobę. Odporność rasowo-specyficzną, tzw. pionową, warunkowaną przez pojedyncze geny oraz odporność poligeniczną, czyli poziomą warunkowaną przez wiele genów rasowo niespecyficznych (Delourme i wsp. 2006). Efektywność tej ostatniej bywa dość zmienna, ale jest bardziej długotrwała. Ze względu na możliwość załamania się odporności wskutek zmian zachodzących w populacji L. maculans, hodowcy dążą do wytworzenia odmian, które łączyłyby oba źródła odporności, tj. odporność specyficzną z pojedynczym genem i odporność poziomą niespecyficzną (Bartkowiak-Broda i wsp. 2017). Obecnie jedna czwarta wszystkich zarejestrowanych w naszym kraju odmian posiada rasowo-specyficzny gen odporności na porażenie przez L. maculans, w zdecydowanej większości jest to gen $R \operatorname{lm} 7$. Badanie składu populacji izo-

Tabela 6. Plonowanie [t/ha] wybranych odmian rzepaku ozimego w warunkach infekcji przez Plasmodiophora brassicae (PDO 2018/2019)

Table 6. Yield [t/ha] of selected varieties of winter oilseed rape under the conditions of infection by Plasmodiophora brassicae (PDO 2018/2019)

\begin{tabular}{|c|c|c|c|c|}
\hline $\begin{array}{l}\text { Odmiana } \\
\text { Cultivar }\end{array}$ & $\begin{array}{l}\text { Wartość średnia } \\
\text { Average value }\end{array}$ & Minimum & Maksimum & $\begin{array}{l}\text { Odchylenie standardowe } \\
\text { Standard deviation }\end{array}$ \\
\hline \multicolumn{5}{|c|}{ Odmiany o podwyższonej odporności - Varieties with increased resistance } \\
\hline Alasco & $3,621 \mathrm{a}$ & 3,282 & 3,841 & 0,2981 \\
\hline Augusta & $4,365 \mathrm{a}$ & 4,086 & 4,780 & 0,3664 \\
\hline DK Platinium & $3,524 \mathrm{a}$ & 2,541 & 4,370 & 0,9219 \\
\hline SY Alibaba & $3,724 \mathrm{a}$ & 3,605 & 3,865 & 0,1313 \\
\hline \multicolumn{5}{|c|}{ Odmiany nieodporne - Susceptible varieties } \\
\hline Architect & $0,549 \mathrm{~b}$ & 0,006 & 1,636 & 0,9411 \\
\hline DK Expiro & $1,661 \mathrm{~b}$ & 0,006 & 2,925 & 1,4982 \\
\hline ES Valegro & $0,957 \mathrm{~b}$ & 0,006 & 2,022 & 1,0126 \\
\hline SY Ilona & $0,578 \mathrm{~b}$ & 0,006 & 1,304 & 0,6626 \\
\hline $\operatorname{NIR}(0,05)-\operatorname{LSD}(0.05)$ & 1,459 & - & - & - \\
\hline Statystyka $F-F$-Statistic & $10,69 * * *$ & - & - & - \\
\hline
\end{tabular}




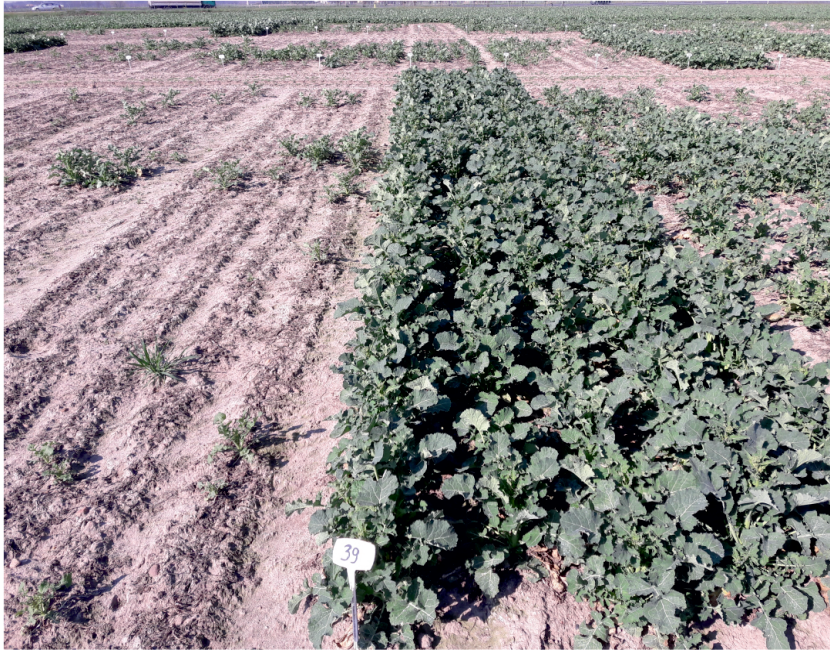

Fot. 1. Poletko z odmianą o potwierdzonej odporności na Plasmodiophora brassicae, obok poletka, na których wysiane zostały odmiany nieodporne (PDO 2019 - pole z infekcją P. brassicae) (fot. J. Broniarz)

Photo 1. A plot with a cultivar confirmed to be resistant to Plasmodiophora brassicae, next to a plot with susceptible cultivars (PDO 2019 - a field infected with P. brassicae) (photo J. Broniarz)

latów L. maculans na danym terenie wskazuje potrzebę wykorzystania konkretnych genów odporności Rlm w hodowli odpornościowej lub odmian, które niosąc tę odporność powinny być uprawiane w danym regionie (Jędryczka i wsp. 2009). Wprowadzenie do uprawy odmian odpornych zredukowało straty plonu, które wynosiły w Polsce i w Europie Zachodniej w zależności od roku 5-20\% i ograniczyło użycie fungicydów. Na przykład we Francji, gdzie przy rejestracji odmian rzepaku jest wymóg genetycznej odporności na L. maculans, całkowicie zaniechano użycia fungicydów przeciwko Leptosphaeria spp. (Bartkowiak-Broda i wsp. 2017). W latach 2015-2019 do Krajowego Rejestru zostały wpisane 83 nowe odmiany rzepaku ozimego, w tej liczbie było 35 odmian, co stanowi 42\%, które według zgłaszających posiadały gen $R \operatorname{lm} 7$ - odporności na L. maculans. W badaniach urzędowych COBORU przed wpisaniem do Krajowego Rejestru znajduje się obecnie 37 nowych odmian, które zgodnie z deklaracją zgłaszających posiadają geny odporności: $\operatorname{Rlm} 7$ oraz Apr37.

W przypadku innych ważnych chorób rzepaku (zgnilizny twardzikowej, czerni krzyżowych, werticiliozy) trwają intensywne poszukiwania donorów odporności na poszczególne patogeny. Zagrożenie powodowane przez te choroby uzasadnia podjęcie kompleksowych badań w celu otrzymania odmian z genetyczną odpornością. Zidentyfikowanie właściwych genów odporności, głównie w gatunkach pokrewnych, stwarza możliwość ich wprowadzenia przy pomocy metod hodowlanych do nowych odmian. W pracach hodowlanych prowadzi się też stałą selekcję materiałów w zakresie odporności na choroby, wybierając te, które ce- chują się lepszą tzw. odpornością polową (Bartkowiak-Broda i wsp. 2017).

Od kilku lat w naszym kraju obserwowane są objawy w następstwie infekcji roślin rzepaku wirusem żółtaczki rzepy (TuYV - Turnip yellows virus). Wektorami przenoszącymi wirusy są mszyce, głównie mszyca brzoskwiniowa (Myzus persicae), rzadziej mszyca kapuściana (Brevicoryne brassicae) (Juergens i wsp. 2010; Borodynko-Filas 2017). Masowy pojaw mszycy w okresie jesiennego wzrostu roślin w ostatnich sezonach wegetacyjnych mógł być spowodowany wysoką temperaturą i długo trwającą wegetacją, a także ograniczonymi możliwościami stosowania zapraw insektycydowych. Szacuje się, że porażenie plantacji wirusem żółtaczki rzepy może spowodować redukcję plonu nasion o $10-40 \%$. Ochrona upraw rzepaku przed tą chorobą wymaga skutecznego zwalczania mszycy, co w praktyce nie jest łatwe. Innym, bardziej efektywnym sposobem ograniczania skutków porażenia przez wirusa żółtaczki rzepy jest wyhodowanie odmian tolerancyjnych na TuYV. Odmiany posiadające genetycznie uwarunkowaną odporność na wirusa żółtaczki rzepy, w warunkach dużej presji mszycy i tym samym zagrożenia infekcją, wytwarzają plon nasion większy i bardziej stabilny niż odmiany nieodporne. Pierwsze dwie tego typu odmiany zostały wpisane do Krajowego Rejestru w roku 2017. Do roku 2019 do Krajowego Rejestru zostało wpisanych 49 nowych odmian rzepaku ozimego, w tej liczbie było 19 odmian tolerancyjnych na TuYV. Obecnie w badaniach urzędowych COBORU przed wpisaniem do Krajowego Rejestru znajdują się 63 nowe odmiany o deklarowanej przez zgłaszających odporności na TuYV.

\section{Podsumowanie / Summary}

Jednym z podstawowych założeń integrowanej ochrony rzepaku jest uprawa odmian odpornych lub tolerancyjnych na infekcje przez organizmy chorobotwórcze. Badania prowadzone w systemie Porejestrowego Doświadczalnictwa Odmianowego (PDO) pozwalają na stały monitoring najistotniejszych zagrożeń i ich nasilenia oraz odporności odmian na ważne gospodarczo patogeny, w zróżnicowanym środowisku agroklimatycznym. Dzięki temu możliwe jest pełniejsze wykorzystanie postępu odmianowego w produkcji poprzez ułatwienie producentom trafnego wyboru odmian do uprawy w określonych warunkach. Precyzyjny dobór odmiany, zwłaszcza odpornej na czynniki chorobotwórcze, a także na inne niekorzystne zjawiska środowiskowe, jest ważnym elementem integrowanej uprawy i ochrony rzepaku. W rzepaku, postęp w hodowli odpornościowej dokonuje się głównie w odmianach mieszańcowych, dla których tworzy się linie syntetyczne umożliwiające wprowadzanie genetycznej odporności do odmian uprawnych. W ostatnich latach dotyczy to takich ważnych gospodarczo chorób, jak: sucha zgnilizna kapustnych, wirus żół- 
taczki rzepy i kiła kapusty. Należy podkreślić, że obecny poziom dostępności odmian rzepaku ozimego dla potrzeb integrowanej ochrony jest dobry i systematycznie uzupeł- niany. Corocznie przybywa nowych odmian, które cechują się wysoką odpornością na niekorzystne czynniki, nie tylko biotyczne, ale także abiotyczne.

\section{Literatura / References}

Bartkowiak-Broda I., Dobrzycka A., Mikołajczyk K. 2017. Rola hodowli w integrowanej ochronie i produkcji rzepaku. s. 58-71. W: Metodyka integrowanej ochrony rzepaku ozimego i jarego dla doradców (E. Jajor, M. Mrówczyński, red.). Instytut Ochrony Roślin - Państwowy Instytut Badawczy, Poznań, 264 ss.

Borodynko-Filas N. 2017. Wirus żółtaczki rzepy - narastający problem w uprawie rzepaku. Nasz rzepak nr 2 (46): 38-40.

Broniarz J. 2017. Dobór odmian. s. 72-92. W: Metodyka integrowanej ochrony rzepaku ozimego i jarego dla doradców (E. Jajor, M. Mrówczyński, red.). Instytut Ochrony Roślin - Państwowy Instytut Badawczy, Poznań, 264 ss.

Delourme R., Chévre A.M., Brun H., Rouxel T., Balesdent M.H., Dias J.S., Salisbury P., Renard M., Rimmer S.R. 2006. Major gene and polygenic resistance to Leptosphaeria maculans in oilseed rape (Brassica napus). European Journal of Plant Pathology 114 (1): 41-52. DOI: $10.1007 / \mathrm{s} 10658-005-2108-9$

Diderichsen E., Beckmann J., Schondelmeier J., Dreyer F. 2006. Genetics of clubroot resistance in Brassica napus 'Mendel'. Acta Horticulturae 706: 307-311. DOI: 10.17660/ActaHortic.2006.706.35

Diderichsen E., Sacristan M.D. 1996. Disease responses of resynthesized Brassica napus L. lines carrying different combinations of resistance to Plasmodiophora brassicae Wor. Plant Breeding 115 (1): 5-10. DOI: 10.1111/j.1439-0523.1996.tb00862.x

Hirani A.H., Genyi L. 2015. Understanding the genetics of clubroot resistance for effectively controlling this disease in Brassica species. Chapter 1. DOI: 10.5772/60936. W: Plants for the Future (H. El-Shemy, red.). InTech, Rijeka, Croatia. ISBN 978-953-51-2185-5. DOI: $10.5772 / 59292$

Jajor E., Korbas M., Horoszkiewicz-Janka J. 2017. Ograniczanie sprawców chorób. s. 124-143. W: Metodyka integrowanej ochrony rzepaku ozimego i jarego dla doradców (E. Jajor, M. Mrówczyński, red.). Instytut Ochrony Roślin - Państwowy Instytut Badawczy, Poznań, 264 ss

Jajor E., Korbas M., Horoszkiewicz-Janka J., Wójtowicz M. 2010. Wpływ ochrony fungicydowej i warunków meteorologicznych na porażenie odmian rzepaku przez Sclerotinia sclerotiorum. Progress in Plant Protection/Postępy w Ochronie Roślin 50 (3): $1334-1339$.

Jajor E., Wójtowicz M., Pieczul K. 2008. Wpływ warunków hydrotermicznych i terminu ochrony fungicydowej na występowanie grzybów z rodzaju Alternaria na rzepaku. Progress in Plant Protection/Postępy w Ochronie Roślin 48 (3): 1048-1054.

Jędryczka M. 2006. Epidemiologia i szkodliwość suchej zgnilizny kapustnych na rzepaku ozimym w Polsce. Rozprawy i Monografie. Instytut Genetyki Roślin Polskiej Akademii Nauk, Poznań, 150 ss.

Jędryczka M., Stachowiak A., Olechnowicz J., Karolewski Z., Podleśna A. 2009. Porównanie zestawu genów awirulencji i ras z kolekcji izolatów chorobotwórczych grzyba Leptoshaeria maculans w Polsce. Rośliny Oleiste - Oilseed Crops 30 (2): 197-205.

Juergens M., Paetsch C., Kramer I., Zahn M., Rabenstein F., Schondelmaier J., Schliephake E., Snowdon R., Friedt W., Ordon F. 2010. Genetic analyses of the host-pathogen system Turnip yellows virus (TuYV) - rapeseed (Brassica napus L.) and development of molecular markers for TuYV-resistance. Theoretical and Applied Genetics 120: 735-744. DOI: 10.1007/s00122-009-1194-Z

Korbas M., Horoszkiewicz-Janka J., Jajor E. 2008. Uproszczone systemy uprawy a występowanie sprawców chorób. [Simplified systems of soil management in relation to the occurrence of disease casual agents]. Progress in Plant Protection/Postępy w Ochronie Roślin 48 (4): 1431-1438.

Korbas M., Jajor E., Budka A. 2009. Clubroot (Plasmodiophora brassicae) - a threat for oilseed rape. [Kiła kapusty (Plasmodiophora brassicae) zagrożeniem dla rzepaku]. Journal of Plant Protection Research 49 (4): 463-468.

Kurowski T.P., Budzyński W. 2003. Wpływ zróżnicowanego nawożenia azotem i ochrony przed szkodnikami na zdrowotność rzepaku jarego. Rośliny Oleiste - Oilseed Crops 24 (2): 455-463.

Majchrzak B., Kurowski T.P., Karpińska Z. 2002. Zdrowotność jarych roślin krzyżowych a grzyby zasiedlajace ich nasiona. [The health condition of spring oilseed crops in relation to the fungi colonising their seeds]. Acta Agrobotanica 55 (1): 199-210. DOI: 10.5586/ aa.2002.019

Mrówczyński M. (red.). 2013. Integrowana ochrona upraw rolniczych. Podstawy integrowanej ochrony. Państwowe Wydawnictwo Rolnicze i Leśne, Poznań, 153 ss.

Ricarova V., Kaczmarek J., Strelkov S., Kazda J., Lueders W., Rysanek P., Manolii V., Jędryczka M. 2016. Pathotypes of Plasmodiophora brassicae causing damage to oilseed rape in the Czech Republic and Poland. European Journal of Plant Pathology 145: $559-572$. DOI: 10.1007/s10658-016-0939-1

Rimmer S.R., Shattuck V.I., Buchwaldt I. 2007. Compendium of Brassica Diseases. American Phytopathological Society (APS Press), St. Paul, USA, 117 ss. ISBN 978-089-05-43-443.

Rolfe S.A., Strelkov S.E., Links M.G., Clarke W.E., Robinson S.J., Djavaheri M., Malinowski R., Haddadi P., Kagale S., Parkin I.A., Taheri A., Borhan M.H. 2016. The compact genome of the plant pathogen Plasmodiophora brassicae is adapted to intracellular interactions with host Brassica ssp. BMC Genomics 17: 272. DOI: 10.1186/s12864-016-2597-2

Strelkov S.E., Tewari J.P., Smith-Degenhardt E. 2006. Characterization of Plasmodiophora brassicae populations from Alberta, Canada. Canadian Journal of Plant Pathology 28 (3): 467-474. DOI: 10.1080/07060660609507321 